\title{
Project Work Model of Lectures in the Department of Special Needs Education
}

\author{
Endang Rochyadi, Rona Wulandari \\ Department of Special Education Needs, \\ Indonesia University of Education, \\ 40154 Bandung, Indonesia \\ endersyam@yahoo.co.id
}

\begin{abstract}
Teaching is a professional job that demands complex abilities, especially for special education teachers, so that not everyone can do the job properly. There is a set of abilities that special education teachers must possess which are known as teacher competencies, one of which is pedagogical competence. Pedagogical competence is concerned with the ability to actualize various potentials in the learning of special needs students. To actualize competencies for prospective teachers (students), the special education study program approaches the project work in the lecture process. The application of this approach in lectures is intended to build the knowledge, understanding, and skills of prospective special education teachers (students) in their real experience by applying various theories to then be reviewed and developed in a multi-layered manner so that alternative solutions are found to teach learners with special needs and reach according to the needs of each student. The method used in this study is qualitative with descriptive analysis with research subjects being special education study program for students in the course development of children with disabilities, assessment, learning and early intervention. Results of this study indicate that through the project works approach students have an understanding and skills in implementing the learning process both in inclusive education settings and in special schools with products produced in the form of assessment guides and programs that are ready to be disseminated to various schools inclusive in the form of community service.
\end{abstract}

Keywords—project work models; lectures; special education programs Introduction.

\section{INTRODUCTION}

The University is a source of academic training and scientific knowledge [1]. Learning orientation at universities, especially in education students is directed at the formation of prospective educators (students) to learn to be teachers [2] and have meaningful learning experiences in the form of skills, attitudes, and moral values that are in accordance with the professions [3].

One component of the academic community in implementing education at the university is a lecturer. Lecturers are professional and scientific educators with the task of transforming, developing and disseminating science, technology, and art through education, research and community service (RI Law No. 14 of 2005 concerning Teachers and Lecturers). Lecturers are responsible for providing knowledge and assessing students' understanding of the knowledge that has been given [4]. This shows that the lecturer is an important figure in the theoretical model that conceptualizes its excellence in the academic field in relation to the development of expertise [5]. The implication is that lecturers are required to have competence currently transferring their knowledge to students. One of the competencies that must be possessed is pedagogical competence; this competence refers to the role of the lecturer as an educational facilitator [6].

Pedagogical competence is the ability of an individual to use various resources such as mastery of articles, cases, and technology (software and hardware) and intangible resources (eg knowledge, skills, experience) to achieve pedagogical effectiveness [7]. Pedagogical competence focuses on the ability to solve problems and tasks that occur in pedagogical activities through the application of knowledge, experience, values, and skills in creative ways [8].

The implementation of pedagogical competence in the special education study program is realized through the selection of the lecture implementation model. The goal achieved through the lectures provided is to prepare students as prospective special education teachers so that they have the knowledge, understanding, and skills in applying the knowledge to serve the needs of students with special needs both in inclusive education settings and in special schools. The learning model used in lectures in special education study programs is a project-based learning model.

Project-based learning is one of the student-centered teaching models [9]. The characteristics of this model are the existence of students' independence in data collection, goal setting, collaboration, communication, and reflection in real practice [10]. Project-based learning is provided through authentic questions and problems in real-world practices [11]

Project-based learning is actualized in the form of work projects based on the process, creativity, and activities of students in learning so that it has an impact on improving student learning outcomes. Project-based learning emphasizes students to be able to learn independently by solving problems faced so that they can produce a project or real work [12]. The advantage of project-based learning is to increase opportunities for students to develop high-thinking, creative, and innovative skills [13] independently and improve conceptual analysis systematically and document and reflect learning [14]. 
Some courses taught with this model include early intervention, assessment, assistive technology, development of children with disabilities and giftedness and learning in special education. The approach in this study is the task of analyzing and implementing the theory that has been taught so that students actualize it and document it in the form of products in the form of various validated guidelines in five subjects, such as interventions for families with special needs children, and assessment guides (academic \& development) which are ready to be implemented in serving students with special needs both in inclusive education schools and special schools.

Several studies that are relevant to the problem raised, namely the case study of project-based learning approaches in China by $\mathrm{Xu} \&$ Liu (2010) conducted in postgraduate education and research results show that project-based learning can increase creativity, collaboration ability, and direct students to be able to reach the target of lectures [15]. Reference [16] raised the issue of improving student learning outcomes with project-based learning that the results of this study significantly improve student learning outcomes in Mathematics Learning to plan courses, active students in lectures, more motivated to learn, and increase cooperation between students [16]. This study is different from previous studies because it is done in lectures on special education courses in five courses, namely assessment, development of children with disabilities and giftedness, assistive technology, and learning in special education, as well as early intervention. The objective of research is to understand.

\section{METHOD}

This research is carried out descriptively that aims to describe the situation or event [17]. The description in this study is a description of the implementation of project-based lectures carried out by special education study programs. The subjects in this study were students who numbered fifty-seven people and were divided into two classes. The first class consisted of twenty-five students, while the second class consisted of twenty-two people. Each class had the same subject and the implementation of the project work model was given in the course of the early intervention, assessment, and learning in special education. The selection of subjects was based on purposive sampling based on certain considerations [18]. The criteria used in sample selection were based on subjects in special education study programs that apply for project work as a lecture model. Data collection was done through observation, interviews, and documentation. Observations and interviews were conducted by asking and observing student performance from the beginning of presenting the problems raised to the final presentation focusing on the final product as a solution to the problems in the field.

\section{RESULT AND DISCUSSION}

The process of implementing the project works model in lectures can be described as in the table below:
TABLE I. TABLE I. Process of IMPLEMENTING THE PROJECT Works MODEL

\begin{tabular}{|l|l|}
\hline \multicolumn{1}{|c|}{ Discussion Topic } & \multicolumn{1}{c|}{ Speaker } \\
\hline The direction of the lecture process & LECTURER \\
\hline Lecture scenarios and projects work & IDEM \\
\hline Theory & IDEM \\
\hline Theory & IDEM \\
\hline Theory & IDEM \\
\hline Work plan preparation (project work) & IDEM \\
\hline Field experience & \\
\hline Idem & \\
\hline Work plan presentation & $1-2-3$ GROUP \\
\hline Idem & GROUP 4-5-6 \\
\hline Independent work & \\
\hline Progress report & $1-2-3$ GROUP \\
\hline Progress report & GROUP 4-5-6 \\
\hline Full report presentation & GROUP 1-2 \\
\hline Full report presentation & $3-4$ groups \\
\hline Full report presentation & GROUP 5-6 \\
\hline
\end{tabular}

Implementation in lectures with a project work model can be procedurally visualized as in the following chart:

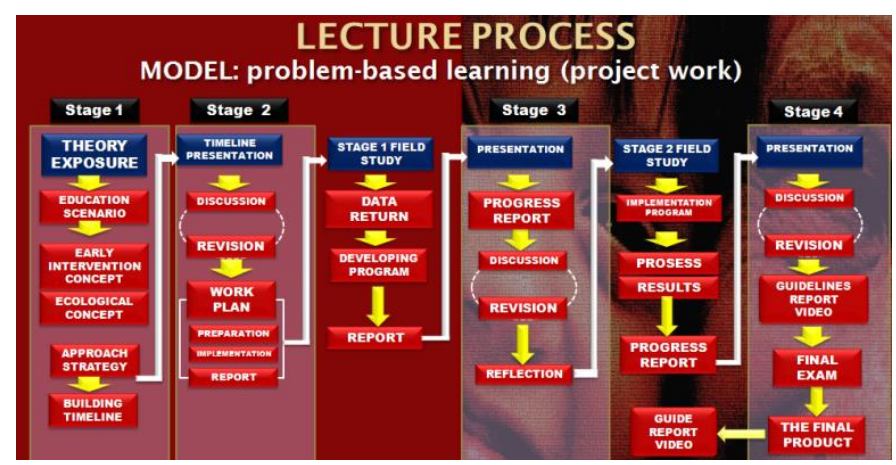

Fig. 1. Lecture process

The application of the project works in lectures was divided into four stages and each stage was organized into a number of lecture meetings. All stages of the lecture implementation were intended for all students, including students with disabilities who attended lectures in special education courses. Phase one and two focused on student preparation, through the provision of theories related to subjects with the project works model, introduction of the lecture implementation system, presentation of field experiences, and presentation of the results of the first field study which at the same time becomes the beginning of monitoring and assessment of success by the lecturer. It was to find out the performance students in achieving the target of each lecture meeting. The third phase was carried out by presenting the program that was prepared based on the first field results, revisions, and representation of the program so that the programs that had been validated were based on children's needs. The fourth stage was carried out by implementing a second field study which aimed to implement a program that had been validated, then the results obtained are presented through a video report and accompanied by a draft program based on the results of the trials that had been obtained. Next step in this stage was the final test by presenting all the results of the implementation of the lecture accompanied by the collection of products in the form of video guides and reports. 
There are three results obtained by students through lectures with the project works model, which are changes in attitudes in attending lectures, ability in making products as solutions to problem-solving in the field, and academic achievement. Changes in attitude that occur in students are in the form of high motivation, commitment to cooperation in groups to meet the target of each lecture meeting, increased activity and enthusiasm as shown in the question and answer in discussion, and arguing based on data and theory. Each subject has a different product in the assessment and development of children with disabilities and giftedness courses in the form of guidance on the implementation of academic assessment and development. Products from early intervention courses are family-based, learning in special education, and assistive technology which are intervention program documents for families with special needs children at an early age. Learning services for children with special needs that can be applied in schools providing inclusive education or special schools, as well as technology that facilitates movement and mobility for individuals with disabilities. There are also academic achievement obtained shown by $90 \%$ of students having A grades and $10 \%$ of students getting A-scores. Besides academic achievement, there is also a high attitude of cooperation and mutual respect for all students including students with disabilities.

University has a role of providing knowledge in a predetermined and designed way in obtaining formal degrees through a series of processes such as research, on the job training, internships, and independent learning [19]. Universities as institutions that produce a variety of graduates, including teacher candidates, need to prepare students' competencies to have certain competencies based on selected programs [20].

Lecturers and students are the two main elements in university education and play a role in regulating the direction of education. To realize students as prospective teachers who have pedagogical competence, lecturers are required to be able to provide active lectures so that students have a comprehensive and in-depth understanding. The involvement of students in active lectures is different from learning in elementary and secondary schools. At the university level, lectures lead to exploration of high-level thinking skills. Students are invited to think, cooperate, exchange ideas and express ideas openly. One way for students to be involved in active lectures is through the selection of the right learning model.

One of the commonly used university learning models, including special education study programs, is project-based learning, which is briefly defined as a learning model related to the project [21]. Project-based learning focuses on encouraging students to face problems through concepts that have been taught, involving students in in-depth data collection, and requiring collaboration between individuals to overcome the problems faced [22]. Project-based learning is actualized in project work activities.

The implementation of the project works in lectures in the special education study program influences the attitudes of students during the lectures, the products produced, and the academic achievement obtained. The attitude is shown in the form of learning motivation, good commitment in working with groups, and high enthusiasm of students during the lecture. Project-based learning makes students more motivated [23] because of the satisfaction with the lectures [24], training time management to reach each lecture timeline [25], enjoying learning in groups, the content of the project itself, or enjoying the change from traditional approaches to project-based learning [26].

All students in special education study programs including students with disabilities can make products based on the tasks assigned. This shows that the lecture model of the project works can provide knowledge, deep understanding and experience, especially to solve problems related to children with special needs. Project-based learning can direct teamwork to produce products that have useful and beneficial values [27]. The balance between theory and practice in the project works contributes to the understanding of students' learning [28].

The application of project-based learning can improve student learning outcomes [29]. This is also done by lecturers in special education study programs, by giving high grades based on the process and achievement of the lecture objectives. Learning outcomes are abilities possessed after receiving learning experiences. Learning outcomes are seen through evaluations that aim to obtain evidence of the level of students' ability to achieve learning goals [30].

Project-based learning provides understanding and experience through solving practical and real problems [31], developing an understanding of deep processes, enhancing independent learning [32], linking and integrating relationships between courses, and providing experience-based life experiences [33]. Based on the process and results obtained by students through the lectures given, this shows that students of special education study programs have the competence to serve the needs of children with special needs both in learning settings in schools providing inclusive education and special schools.

\section{CONCLUSION}

Lectures with project work models can provide meaningful learning for all students, including students with disabilities in special education study programs. The success of the lecture with the project work model can be seen from the positive attitude of students (such as enthusiasm and high motivation) during the lecture, being able to make products based on problems encountered in the field, and getting good learning outcomes based on the process and products achieved as the final goal from each subject. This shows that students with specialized study programs have the competence to become teacher candidates who are ready to serve the religious needs of children with special needs.

\section{REFERENCES}

[1] S. Paleari, D. Donina, and M. Meoli, "The role of the university in twenty-first century European society," The Journal of Technology Transfer, vol. 40, no. 3, pp. 369-379, Jun. 2014.

[2] M. F. Hidayatullah, Mengantar Calon Pendidik Berkarakter di masa depan. Surakarta: UNS Press dan Cakra Books, 2007. 
[3] N. Y. Rustaman of B. Fatmawati, "Pembelajaran berbasis proyek untuk meningjatkan keterampilan berfikir kreatif mahasiswa," Jurnal Pengajaran MIPA, vol. 16, no. 2, pp. 85-92, 2011.

[4] M. Cosmas, and C. Ndebele, "Interrogating the skill of introducing a lecture: towards an interactive lecture method of instruction," The Anthropologist, vol. 17, no.2, pp. 543-550, 2014

[5] S. Monteiro, L. S. Almeida, R. M. Vasconcelos, "The role of teachers at university: What do high achiever students look for?" Journal of the Scholarship of Teaching and Learning, vol. 12, no.2, pp. 65-77, Jun. 2012

[6] E. Ammenwerth, "Envisioning changing role of university teacher in online instructional environments*," AISHE-J, vol. 9, no. 3, pp. 31213129, 2017.

[7] S. Madhavaram, and D. A. Laverie, "Developing pedagogical competence: issues and implications for marketing education," Journal of Marketing Education, vol. 20, no. 10, pp. 2-10, 2010.

[8] A. I. Suciu, and L. Mata, "Pedagogical competences," International Online Journal of Educational Sciences, vol. 3, no. 2, pp. 411-423, 2011.

[9] N. R. Ergül and E. K. Kargın, "The Effect Of Project Based Learning On Students' Science Success," Procedia - Social and Behavioral Sciences, 136, pp. $537-541,2014$

[10] D. Kokotsaki, V. Menzies, and A. Wiggins, "Project-based learning: A review of the literature," Improving Schools, vol. 19, no. 3, pp. 1-11, Jul. 2016

[11] S. M. Al-Balushi and S. S. Al-Aamri, "The effect of environmental science projects on students' environmental knowledge and science attitudes," International Research in Geographical \& Environmental Education, vol.23, no. 3, pp. 213-227, Jun. 2014.

[12] N. W. Rati, N. Kusmaryatni, and N. Rediani, "Project based learning models, creativity and student learning outcomes. Indonesian Journal of Education, vol. 6, no. 1, Mar. 2017.

[13] K. Beswick, R. Callingham, and T. Muir, "Teaching mathematics in a project-based learning context: Initial teacher knowledge and perceive needs," in Mathematics Education: Expanding Horizons: Proceeding of the 35th Annual Conference of the Mathematical Education Research Group of Australasia, Australasia, 2012, p. 1-8.

[14] M. Barak, 'From 'doing' to 'doing with learning': Reflection on an effort to promote self-regulated learning in technological projects in high school," European Journal of Engineering Education, vol. 37, no. 1, pp. 105-116, Feb. 2012

[15] Y. Xu, and W. Liu, "A project-based learning approach: a case study in China," Asia Pacific Education Review, vol.11, no. 3, pp. 363-370, 2010

[16] S. N. Mayangsari, "Peningkatan hasil belaajr mahasiswa dengan project based learning (PBL),” LIKHITAPRAJNA Jurnal Imliah, Vol. 19, no. 2, pp. 33-43, Sept. 2017.

[17] Marsigit, Kajian penelitian pendidikan matematika: Materi matrikulasi S2 pendidikan matematika. Yogyakarta: PPS Universitas Negeri Yogyakarta, 2012.

[18] Sugiyono, Metodologi Penelitian Kuantitatif, Kualitatif, dan R\&D. Bandung: CV Alfabeta, 2016.

[19] M. Brady, "Multiple roles of student and instructor in university teaching and learning processes," The International Journal of Management Education, vol. 11, no. 2, pp. 93-106, 2013.

[20] Ramlawati, A. Mun'im, and S. R. Yunus, "Improving pedagogical competences of prospective science teachers to develop learning materials through jigsaw cooperative model," Journal of Physics: Conference Series, vol. 1028, no. 1, pp. 1-6, Jun. 2018.

[21] M. Hugerat, "How teaching science using project-based learning strategies affects the classroom learning environment," Learning Environments Research, vol. 19, no. 3, pp. 383-395, 2016.

[22] K. J. Chua, W. M. Yang, and H. L. Leo, "Enhanced and conventional project-based learning in an engineering design module," International Journal of Technology and Design Education, vol.24, no. 4, pp. 437-458, 2014.

[23] S. Fernandes, M. A. Flores, and R.M. Lima, "Students' views of assessment in project-led engineering education: findings from a case study in Portugal," Assessment \& Evaluation in Higher Education, vol. 37, no. 2, pp. 163-178, 2012.

[24] K. Edström, and A. Kolmos, "PBL and CDIO: complementary models for engineering education development," European Journal of Engineering Education, vol. 39, no. 5, pp. 539-555, 2014

[25] C. A. Vitranti, "Pembelajaran berbasis proyek pada matakuliah phb untuk mendukung kompetensi calon guru matematika (project based learning in assessment lecture to encourage the competence of perspective teacher of mathematics)," Jurnal Matematika dan Pendidikan Matematika, vol. 2, no. 1, Mar. 2017.

[26] P. J. Beres. (2011). Project-based learning and its effect on motivation in the adolescent mathematics classroom. Education and Human Development Master's Theses. State University of New York. [Online] Available: http://digitalcommons.brockport.edu/ehd_theses/39

[27] E. S. Zancul, T. T. Sousa-Zomer, and P. A. Cauchick-Miguel, "Projectbased learning approach: improvements of an undergraduate course in new product development," Production, vol. 27, pp. 1-14, Jul. 2017.

[28] A. H Schoenfeld, Mathematics Teaching and Learning, 2nd ed. USA: Barkeley, 2005

[29] S. Hutasuhut, "Implementasi pembelajaran berbasis proyek (prohect based learning) untuk meningkatkan motivasi dan hasil belaajr mata kuliah pengantar ekonmi oembangunann daoa juruan manjemen FE Unimed," Pekbis Jurnal, vol. 2, no. 1, pp. 196-207, Mar. 2010.

[30] A. Jihad, and Abdul Haris, Evaluasi Pembelajaran. Yogjakarta: Multi Pressindo, 2013

[31] M. J. Terrón-López, M. J. Garcia, P. J. V. Quintana, and M. GayaLopez, "Implementation of a project-based engineering school: increasing student motivation and relevant learning," European Journal of Engineering Education, vol. 41, no. 5, pp. 618-631, Jul. 2016.

[32] K. W. Chau, "Problem-based learning approach in accomplishing innovation and entrepreneurship of civil engineering undergraduates,' International Journal of Engineering Education, vol. 21, no. 2, pp. 228 232, 2005.

[33] J. Song, and D. E. Dow, "Project-based learning for electrical engineering lower-level courses," in Proc. of the 123rd ASEE Annual Conference and Exposition, New Orleans, 2016, p. 1-10. 